\author{
Ewa M. Guzik-Makaruk \\ University of Białystok \\ ewa.guzik@uwb.edu.pl \\ Ewelina Wojewoda \\ University of Białystok \\ ewelina.wojewoda@onet.pl
}

\title{
Offences Against Elections and Referenda - Selected Legal, Criminal and Criminological Aspects
}

\begin{abstract}
This research paper elaborates on the problem of offences against elections and referenda, and analyses provisions of the XXXI Chapter of the Polish Penal Code, penalizing electoral offences. A detailed description of particular acts prohibited by law has been provided. Moreover, attention is given to issues causing interpreting problems. The paper presents a statistical overview of the occurrence of offences on the basis of data concerning initiated proceedings, and convictions by finaljudgments.
\end{abstract}

Keywords: offences against elections and referenda, electoral abuse, disruption of elections, abuse of the freedom to vote, electoral corruption, infringement of the votingconfidentiality

Słowa kluczowe: przestępstwa przeciwko wyborom i referendum; nadużycia wyborcze; zakłócanie przebiegu wyborów; naruszenie swobody głosowania; łapownictwo wyborcze; naruszenie tajności głosowania

\section{Introduction}

One can find a thesis in the literature that the origin of offences against elections should be sought in the Ancient Rome, where election abuses took forms of various briberies. However, formed legal constructions of the respective types of election offences, as well as the election process itself appeared in constitutional monarchies 
in the XIX century ${ }^{1}$. This kind of offences was penalized in the Penal Code of $1932^{2}$, in its successor of $1969^{3}$, as well as in the currently binding Penal Code. In the Penal Code of 1932, such regulation was provided for in Chapter XX broadly titled as: 'Offences against voting'. It is worth mentioning that the 1932 Code was a model for creation of provisions of Chapter XXXI of the current penal act of $1997^{4}$.

The aim of this paper is to present legal, criminal and criminological aspects of offences against elections and the present scale of this phenomenon. Undertaking this subject matter resulted from the fact that committing offences penalized in the Chapter XXXI of the Penal Code disrupts proper functioning of democracy, thus it constitutes a particularly important issue from the state's point of view.

Provisions of this Chapter play a very important role in a democratic state, as they protect the core institutions of this system. They safeguard proper functioning of exercising the power by the nation, both in indirect and direct forms. Undoubtedly, major importance of these regulations results from the fact that through elections citizens decide about the head of state, composition of both chambers of the Parliament, bodies of regional government, and - since 2004 - also the European Parliament. Whereas, in a referendum they answer questions concerning matters particularly important for the state.

Therefore, an in-depth analysis of features of respective prohibited acts is necessary to a good understanding of the present wording of the Chapter XXXI and indicating issues rising controversies in the dogmatics. There are many valuable papers in the subject-matter literature devoted to the issue of election offences. Due to the fact, however, that elections and referenda are an integral part of our system, there permanently exists a need to present the current scale of this phenomenon and to describe regularities governing it. This is why the article presents the actual size of offences against elections and referenda, what the latest data concerning a number of proceedings instituted for a specific prohibited act and a number of persons convicted under the given provision are for, what allows drawing conclusion on threat of this category of offences.

A generic object of protection under provisions of Articles 248-250 of the Penal Code is the correct course of the elections ${ }^{5}$ to: the Sejm, the Senate, bodies of local

1 W. Kozielewicz, Rozdział IX. Przestępstwa przeciwko wyborom i referendum, (in:) L. Gardocki (ed.), System Prawa Karnego. Przestępstwa przeciwko państwu i dobrom zbiorowym, t. 8, Warszawa 2012, p. 710, 711.

2 Rozporządzenie Prezydenta Rzeczypospolitej Polskiej z mocą ustawy z dnia 11 lipca $1932 \mathrm{r}$. (Dz.U. z 1932 r. Nr 60, poz. 571 z późn.zm.) [Journal of Laws of 1932 No. 60 item 571 as amended].

3 Ustawa z dnia 19 kwietnia 1969 r. - Kodeks karny (Dz.U. z 1969 r. Nr 13, poz. 94 z późn. zm.) [Journal of Laws of 1969 No. 13 item 94 as amended].

4 W. Kozielewicz, Rozdział..., op. cit., p. 710, p. 711.

5 J. Piskorski, Przestępstwa przeciwko wyborom i referendum, (in:) M. Królikowski, R. Zawłocki (eds.), Kodeks Karny.Część Szczególna. Komentarz do art. 222-316, Warszawa 2013, p. 257. 
government, the European Parliament and elections for the President of the Republic of Poland, as well as referenda. Electoral law is protected both in nationwide and individual aspects. These regulations are to guarantee holding of elections to the aforementioned bodies and referenda in a reliable way, in accordance with the law and principles of democracy, as well as exercising citizens'electoral law ${ }^{6}$.

The binding Penal Code describes criminal behaviors related to the process of elections and referenda, both nationwide and local, in a very precise and casuistic way. It is worth noting that there is a number of prohibited acts directed against these institutions, provided for in other legal instruments, namely Electoral Code ${ }^{7}$, Act on nationwide referendum ${ }^{8}$ and Act on local referendum ${ }^{9}$.

\section{Electoral abuses (Article 248of the Penal Code)}

Article 248 of the Penal Code ${ }^{10}$ penalizes violations of electoral and referendum law in the conduct of the elections (so-called electoral abuses). There can be found extremely different views in the literature concerning the object of acts typified in this provision. A. Marek claims that the electoral abuse is a common offense ${ }^{11}$, meaning that every person, who is capable of being held criminally liable, that is who reached the age of criminal responsibility and is not mentally incompetent, can be the object of criminalized acts. M. Szewczyk notes that only persons responsible for preparation of lists of candidates and voters can be perpetrators of acts under pts 1 and 2. Above all, a member of electoral committee, which is responsible for safeguarding the proper course of accepting and counting votes, can be the object of an offense typified in pt

6 M.Budyn-Kulik, Komentarz do rozdziału XXXI k.k., (in:) M.Mozgawa (ed.), M.Budyn-Kulik,P. Kozłowska-Kalisz,M. Kulik, Kodeks Karny. Komentarz, Warszawa 2012, p. 579.

$7 \quad$ Ustawa z dnia 5 stycznia 2011r. - Kodeks wyborczy (Dz.U. z 2011 r. Nr 21, poz. 112 z późn. zm.) [Journal of Laws of 2011 No. 21 item 112 as amended].

8 Ustawa z dnia 14 marca 2003r. - o referendum ogólnokrajowym (Dz.U. z 2003 r. Nr 57, poz. 507 z późn.zm.) [Journal of Laws of 2003 No. 57 item 507 as amended].

9 Ustawa z dnia 15 września 2000r. - o referendum lokalnym (Dz.U. z 2000 r. Nr 88 poz. 985 z późn. $\mathrm{zm}$.) [Journal of Laws of 2000 No. 88 item 985 as amended].

10 Article 248. Anyone who, in connection with elections to the Sejm or the Senate, or elections for the President of the Republic of Poland, elections to the European Parliament, or local elections or a referendum: 1) prepares a list of candidates or voters not including eligible people or including ineligible people, 2) uses deceit in order to improperly prepare the list of candidates, the electoral roll, protocols or other electoral or referendum documents, 3) destroys, damages, hides, forges or remakes protocols or other electoral or referendum documents, 4) interferes or allows interference with the collection or counting of votes, 5) provides another person, before voting has ended, with an unused ballot paper,or obtains an unused ballot paper from another person in order to use it for voting, 6) commits an abuse while preparing a list with the signatures of citizens who put forward candidates for elections, or to initiate a referendum - is liable for imprisonment for up to three years.

11 A. Marek, Kodeks Karny. Komentarz, Warszawa 2010, p. 540. 
4. The perpetrator of an offense under pt 6 can be a person who prepares lists with signatures of citizens submitting candidates for elections or initiating a referendum ${ }^{12}$. L. Tyszkiewicz emphasizes however, that although the discussed offense is not an individual offense, it may be committed most of all by a person participating in the election or referendum procedure ${ }^{13}$. J. Piskorski claims that acts typified in pts $1,2,4$ and 6 belong to a group of individual offences, an act under pt 3 is however a common offence. Criminal behavior provided for in pt 5, in part concerning ceding a ballotpaper to another person, is an individual offence, as it should be assumed that only a voter can come into its possession. Whereas, behavior consisting in obtaining a ballot paper will be acommon offence ${ }^{14}$.

This provision's individual object of protection is legality of voting ${ }^{15}$. The legislator, in Article 248 of the Penal Code, precisely itemizes types of criminal behavior, which constitute electoral abuses.

Behavior penalized in pt 1 consists in preparing lists of candidates or voters, excluding eligible persons, or including ineligible persons. This act can be committed by both action and omission. It is an offence with criminal consequences from exposing to a concrete danger. Preparation of a list of candidates or voters inconsistent with the law is a result belonging to the features of this prohibited act $^{16}$.

Pt 2 of Article 248 of the Penal Code criminalizes usage of deceit in order to improperly prepare lists, protocols, or other electoral and referendum documents. This offence is of a formal character and may be committed by both action and omission ${ }^{17}$. The term 'document' used in the wording of this provision shall be defined in accordance with Article $115 \$ 14$ of the Penal Code ${ }^{18}$.

$\mathrm{Pt} 3$ stipulates criminal responsibility for: destroying, damaging, hiding, forging or remaking protocols and other electoral and referendum documents ${ }^{19}$. It is a substantive offence, which can be committed only as a result of perpetrator's action $^{20}$. According e construed as total destruction or significant infringement of the item's substancto the theses of Article $288 \S 1$ of the Penal Code, the term

12 M. Szewczyk, Przestępstwa przeciwko wyborom i referendum, (in:) A. Zoll (ed.), Kodeks Karny. Komentarz do art. 117-277 k.k., Warszawa 2013, p. 1319.

13 L. Tyszkiewicz, Przestępstwa przeciwko wyborom i referendum, (in:) M. Filar (ed.), Kodeks Karny. Komentarz, Warszawa 2012, p. 1164 and A. Marek, Kodeks..., op. cit.

14 J. Piskorski, Przestępstwa..., op. cit., p. 256.

15 M. Budyn-Kulik, Komentarz..., op. cit., p. 580.

16 M. Budyn-Kulik, Komentarz..., op. cit., p. 580.

17 Ibidem, p. 580.

18 Article $115 \$ 14$. A document is any object or record on a computer data carrier to which a specific right is attached, or which, in connection with the subject of its content, constitutes evidence of a right, a legal relationship or a circumstance that may have legal significance.

19 See more: S. Kowalski, Karnoprawna ochrona wykazu podpisów wyborców w wyborach samorządowych, "Prokuratura i Prawo" 2014, No. 9.

20 M. Budyn-Kulik, Komentarz..., op. cit., p. 580. 
'destruction' shall be, hindering its usage in accordance with the intended purpose ${ }^{21}$. Generally speaking, this means its annihilation or deprivation of features it has had so far. 'Hiding', simply put, means creating a state of the document's unavailability for eligible persons and willing to use $i^{22}$, locating in a place different than where it should be located, so it is not possible to use it properly ${ }^{23}$. On the basis of Article 270 $\$ 1$, 'forging'means 'making some item to appear as document, in order to create the impression that its contents comes from an issuer it mentions, whereas in fact this is not the case. It refers to both forging the entire document and its excerpt. The term 'remaking' shall be construed as making amendments to the content of the authentic document; it may consist in crossing out, adding insertions, as well as erasing ${ }^{24}$. The Supreme Court in its judgment of 9 January 2013, issued under Article $270 \$ 1$ of the Penal Codestated that: 'A behavior of an offender, who either makes a document to appear that its content comes from the given issuer - which is not true (such behavior is document's 'forging' within the meaning of Article $270 \$ 1$ of the Penal Code), or - in the second form of criminal activity - an offender makes amendments to the content of the authentic document really issued by an issuer entitled to do so (such behavior is document's 'remaking' in the meaning of the Article $270 \$ 1$ of the Penal Code) - shall be subject to penalization ${ }^{25}$.

The next point (4) of Article 248 of the Penal Code, provides for typification of electoral fraudthrough interference or allowing interference while collecting votes, which is a formal offence. The first of verbal features indicates that this offence may be committed by action, whereas the second (allowing interference) unquestionably indicates omission (it is an offence improper from omission) ${ }^{26}$.

It shall be emphasized that the term 'abuse' itself is not very clear and precise, therefore there are critical voices in the literature relativized to its usage by the legislator ${ }^{27}$. It is stressed however, that abuse always has to result from violation of law and obligations resulting from it. The described prohibited act may be committed e.g. by incorrect counting of the cast votes, or destroying ballot papers with cast votes ${ }^{28}$.

Criminal behavior provided for in pt 5 consists in ceding an unused ballot paper to another person, before the voting has ended or obtaining such an unused ballot

21 A. Marek, Kodeks..., op. cit., p. 613.

22 M.Budyn-Kulik, Komentarz..., op. cit., p. 580, p. 641.

23 M. Szewczyk, Przestępstwa..., op. cit., p. 1321.

24 M.Budyn-Kulik, Komentarz..., op. cit., p. 580, p. 631.

25 Wyrok Sądu Najwyższego z dnia 9 stycznia 2013 r., VKK97/12, [Judgment of the Supreme Court of 9 January 2013, V KK 97/12], "Prokuratura i Prawo" 2013, No. 4, "Orzecznictwo" supplement, item 5 .

26 M. Budyn-Kulik, Komentarz..., op. cit., p. 580.

27 L. Tyszkiewicz, Przestępstwa..., op. cit., pp. 1163-1164.

28 A. Marek, Kodeks..., op. cit. 
paper from another person in order to use it for voting. It is a formal offence, which can be committed only by action ${ }^{29}$.

The last one of penalized acts (pt 6) under Article 248 consists in committing an abuse while preparing a list with the signatures of citizens who put forward candidates for elections, or to initiate a referendum. This prohibited act is of a formal character, and can be committed by both action and omission (an offence improper from omission) ${ }^{30}$.

All mentioned minor offences can be committed only with intentional guilt. Therefore, irregularities committed unintentionally will not constitute an offence within the meaning of this provision, even if an error, under which an offender acted, was not justified ${ }^{31}$. Clarifying a form of intentional guilt it should be noted that minor offences, referred to in pts 1, 3, 4 and 6 can be committed both in direct and conceivable intent. The act typified in pt 2 , without any doubt, can be committed only with direct intent, what is unambiguously prejudged by the phrasing in order to. In the case of ceding provided for in pt 5 , two forms of intent are possible; however, when obtaining is concerned, only direct intent is possible ${ }^{32}$.

The offence stipulated in Article 248 of the Penal Code is punished by imprisonment from one moth for up to three years.

As noted by the classic of the Polish criminology B. Hołyst - 'crime is not the statutory expression. Neither it constitutes an element of legal language ${ }^{33}$. Whereas one cannot discuss with the first statement, the second assumption seems incorrect, as criminal lawyers use the term crime on everyday basis, and therefore it became an integral part of the legal language, entering it permanently. It should be repeated after B. Hołyst that, in traditional criminological understanding, crime is a set of prohibited acts punishable under the statute, committed at the specific time in the area of specified territorial unit. Crime is inextricably linked to problems concerning its size, understood as share of criminal behaviors in the overall activity of members of the society ${ }^{34}$. Such understood size of crime consists of the following types: actual crime, disclosed, stated and judged.

Size of the first type are never known, as these are all criminal acts in a given area at a given time. Law enforcement authorities never have full knowledge on that subject, some part of the actual crime is included in the area of so-called 'dark number' of offences. The disclosed crime, often referred to as apparent in the literature, reflects all acts information on which was obtained by law enforcement authorities, and

29 M. Budyn-Kulik, Komentarz..., op. cit., p. 580.

$30 \quad$ Ibidem, p. 580.

31 L. Tyszkiewicz, Przestępstwa..., op. cit., p. 1164.

32 M. Szewczyk, Przestępstwa..., op. cit., pp. 1322-1323.

33 B. Hołyst, Kryminologia, Warszawa 1994, p. 53.

34 Ibidem, p. 54. 
Offences Against Elections and Referenda - Selected Legal, Criminal...

therefore initiated a preparatory proceeding. The stated crime means all acts criminal character of which was confirmed as a result of conducted preparatory proceeding, and crime judged means a set of acts, criminal character of which was confirmed in a court proceeding ${ }^{35}$.

The statistics given below was taken from data presented on the official website of the police ${ }^{36}$, as well as data sent by the National Police Headquarters and placed on the website of the Ministry of Justice ${ }^{37}$. The police statistical data refer to a number of instituted proceedings, what means that they concern the area of so-called disclosed crime, whereas data disclosed in statistics conducted by the Ministry of Justice are sent by courts, preparing criminal charters. The statistics conducted by the Ministry is a court statistics including data on the stated crime.

As rightly pointed by B. Hołyst, scope of recording and efficiency are advantages of the police statistics, whereas its inaccuracy is a disadvantage, as some of recorded acts lack features of an offence. Wide scope of information on an offence and offender, verified in the course of preparatory and court proceedings, is an advantage of the court statistics. The court statistics usually includes lower number of convictions than offences recorded in the police statistics ${ }^{38}$.

Moreover, it should be noted that the police statistics use the statistical unit in the form of a number of instituted proceedings (where can be no suspects, can be one, two or more), whereas the court statistics are based on a number of final convictions of adults. Thus, different reports are used to build these two types of statistics.

Table 1. A number of proceedings instituted under Article 248 of the Penal Code and special acts between 1999 and 2014

\begin{tabular}{|c|c|c|c|c|c|c|c|c|}
\hline & 1999 & 2000 & 2001 & 2002 & 2003 & 2004 & 2005 & 2006 \\
\cline { 2 - 9 } & 71 & 69 & 12 & 12 & 69 & 84 & 46 & 23 \\
\cline { 2 - 9 } $\begin{array}{c}\text { Article 248 } \\
\text { andspecialacts }\end{array}$ & 2007 & 2008 & 2009 & 2010 & 2011 & 2012 & 2013 & $\begin{array}{c}2014 \\
\text { (Article } \\
248)\end{array}$ \\
\cline { 2 - 9 } & 56 & 64 & 23 & 22 & 19 & 33 & 15 & 95 \\
\hline
\end{tabular}

Source: www.policja.pl (accessed on: 25.01.2015).

Prohibited acts in the form of offences and delinquencies under non-code, special acts correspond with the offences described in Article 248 of the Penal Code. These may include Articles 494 - 513a of the Electoral Code ${ }^{39}$, Articles $80-87$ of the

$35 \quad$ Ibidem, p. 54.

36 Website:www.policja.gov.pl (accessed on: 25.01.2015).

37 Website:www.ms.gov.pl (accessed on: 25.01.2015).

38 B. Hołyst, Kryminologia..., op. cit., p. 55, 60.

39 Ustawa z dnia 5 stycznia 2011 r. - Kodeks wyborczy (Dz.U. z 2011 r. Nr 21, poz. 112 z późn. zm.) [Journal of Laws of 2011 No. 21 item 112 as amended]. 
Act on nationwide referendum ${ }^{40}$, Articles $68-73$ of the Act on local referendum ${ }^{41}$, which cover also main financial abuses and illegal electioneering ${ }^{42}$.

Table 2. Adults finally convicted under Article 248 of the Penal Code between 2001 and 2012

\begin{tabular}{|c|c|c|c|c|c|c|c|c|c|c|c|c|}
\hline $\begin{array}{c}\text { Article } \\
248\end{array}$ & 2001 & 2002 & 2003 & 2004 & 2005 & 2006 & 2007 & 2008 & 2009 & 2010 & 2011 & 2012 \\
\hline pt 1 & 2 & 2 & - & 3 & 1 & 2 & 5 & 4 & - & 2 & 1 & 1 \\
\hline pt 2 & 4 & 1 & 2 & 50 & 19 & 5 & 12 & 2 & - & 2 & 2 & 2 \\
\hline pt 3 & 1 & 2 & 6 & 2 & 2 & 4 & 13 & 2 & 7 & 4 & 3 & 1 \\
\hline pt 4 & - & - & - & 1 & - & 1 & - & - & - & - & - & - \\
\hline pt 5 & - & - & - & - & 2 & - & 1 & - & - & - & 4 & - \\
\hline pt 6 & - & - & - & - & - & - & - & 9 & 28 & 21 & 4 & - \\
\hline
\end{tabular}

Source: http://ms.gov.pl/ (accessed on: 25.01.2015).

The largest number of offences under Article 248 of the Penal Code wasinstituted in 2014, in a year when municipal elections took place - as many as 95 proceedings. The attention might also be drawn to data of 2004, when 84 proceedings were initiated (under Article 248 and special acts). It is worth to signal that it was the year when the first European Parliament elections took place in Poland, and which were then added to the catalogue of institutions protected by provisions of the Chapter XXXI of the Penal Code. The lowest number of proceedings for electoral abuses and acts under special statutes was instituted in 2001 and 2002, only 12 proceedings. It should be mentioned that the parliamentary elections took place in 2001, and the municipal elections in 2002. One can repeat after J. Piskorski that offences against elections are not a serious criminal problem in quantitative terms, and correlation between a number of recorded acts and years, when elections take place, is a noticeable regularity ${ }^{43}$.

Observing data concerning final convictions of adults under Article 248 of the Penal Code, one can notice that the largest number of final judgments concerned an act under pt 2, so using deceit in order to improperly prepare lists, protocols, or other electoral and referendum documents. In 2004, as many as 50 persons were convicted, and in 2005 - 19. One can also note a low number of persons convicted (from a few to several persons) under pt 3 (destroying, damaging, hiding, forging or

40 Ustawa z dnia 14 marca 2003 r. - o referendum ogólnokrajowym (Dz.U. z 2003 r. Nr 57, poz. 507 z późn. zm.) [Journal of Laws of 2003 No. 57 item 507 as amended].

41 Ustawa z dnia 15 września 2000 r. - o referendum lokalnym (tekst jedn. Dz.U. z 2013 r., poz. 706) [Journal of Law of 2013 item 706].

42 G. Łabuda, Komentarz do art. 248 k.k., (in:) J. Giezek (ed.), Kodeks karny. Część szczególna. Komentarz, War- szawa 2014, p. 861.

43 J. Piskorski, Przestępstwa..., op. cit., p. 249. 
remaking protocols and other electoral and referendum documents). Conviction for minor offences provided for in pts 1,4 and 5, represents a rare event in practice, and if happens, it concerns only few persons annually. Lack of convictions for an act under pt 5 of Article 248 of the Penal Code before 2004 results from the fact that this was a year when the said provision was added to the Penal Code ${ }^{44}$.

\section{Interference with the conduct of elections (Article 249 of the Penal Code)}

Article $249^{45}$ forms criminal liability for interference with the conduct of elections, which is a common offence. An individual object of protection of this provision is the freedom to exercise electoral law ${ }^{46}$.

The subject regulation aims at ensuring protection for convening an assembly before voting; the free exercising of the right to stand or to vote in election; conducting the voting and counting of votes, as well as drawing up protocols or other electoral or referenda documents.

A causative act of an offence under Article 249 of the Penal Code consists in interference. It is assumed that it means preventing or obstructing the conduct of the aforementioned activities, being the object of protection of this provision ${ }^{47}$. It is an interferencewith a modality, provided for in the law, of exercising by citizens' rights involving participation in an electoral or referendum act ${ }^{48}$.

In accordance with the wording of this provision, the punishable interference must take place with theuse of violence, the unlawful threat or deceit. The violence means physical interaction with an individual, which is to prevent resistance or to overcome it ${ }^{49}$. The unlawful threat of violence is a statutory term, defined in Article $115 \$ 12^{50}$. The deceit consists in misleading the other person in order to enforce the specific conduct ${ }^{51}$. One should also remember to take into consideration theses

44 Ustawa z dnia 23 stycznia 2004 r. - Ordynacja wyborcza do Parlamentu Europejskiego (Dz.U. z 2004 r. Nr 25, poz.219) [Journal of Laws of 2004 No. 25 item 219].

45 Article 249. Anyone who by using violence, the unlawful threat of violence or deceit interferes with: 1) an assembly before voting, 2) the free exercise of the right to stand or to vote in an election, 3) the voting or counting of votes, 4) drawing up protocols or other electoral or referendum documents - is liable to imprisonment for between three months and five years.

46 J. Piskorski, Przestępstwa..., op. cit., p. 261.

47 L. Tyszkiewicz, Przestępstwa..., op. cit., p. 1164.

48 M. Szewczyk, Przestępstwa..., op. cit., p. 1325.

49 Ibidem, p. 1325.

50 Article $115 \$ 12$. An illegal threat is both the threat mentioned in Article 190, and also a threat to bring criminal proceedings, or to spread defamatory information concerning the threatened person or a next of kin. A declaration that criminal proceedings will be instituted is not a threat if made solely to protect a legal right violated by an offence.

51

M. Szewczyk, Przestępstwa..., op. cit., p. 1325. 
resulting from provisions penalizing prohibited acts, to features of which belongs such conduct, when examining the terms violence and threat.

It is the accepted view in the literature that the discussed minor offence is a nonconsecutive, because the legislator did not include the effect to the features of this offence $^{52}$. In a slightly different manner this issue is presented by

L. Tyszkiewicz, who indicates that the discussed act may be a substantive offence. A result, that belongs to the features of the prohibited act, is occurrence of the state of factual difficulties in exercising the aforementioned acts, and not the non-exercise of these acts $^{53}$. Following the said author, switching-off the power in a polling station, during vote-counting, explained with alleged failure, can be given as an example of committing a minor offence under Article 249 of the Penal Code ${ }^{54}$. It is worth mentioning that the said minor offence belongs also to the category of multi-action offences $^{55}$.

The objective side of an offence provided for in Article 249 consists in intent; it is emphasized that the said act can be committed only with the direct intent ${ }^{56}$.

For the discussed minor offence, the legislator envisaged in the Penal Code a penalty of imprisonment from 3 months for up to 5 years.

Table 3. A number of proceedings instituted for an act provided for in Article 249 of the Penal Code between 1999 and 2014

\begin{tabular}{|c|c|c|c|c|c|c|c|c|}
\hline \multirow{4}{*}{$\begin{array}{c}\text { Article } \\
249\end{array}$} & 1999 & 2000 & 2001 & 2002 & 2003 & 2004 & 2005 & 2006 \\
\hline & - & 4 & 9 & 19 & 8 & 3 & 5 & 19 \\
\hline & 2007 & 2008 & 2009 & 2010 & 2011 & 2012 & 2013 & 2014 \\
\hline & 13 & 1 & 2 & 14 & 9 & 1 & - & 11 \\
\hline
\end{tabular}

Source: www.policja.pl (accessed on: 25.01.2015).

Table 4. Adults validly convicted under Article 249 of the Penal Code between 2001 and 2012

\begin{tabular}{|c|c|c|c|c|c|c|c|c|c|c|c|c|}
\hline $\begin{array}{c}\text { Article } \\
249\end{array}$ & 2001 & 2002 & 2003 & 2004 & 2005 & 2006 & 2007 & 2008 & 2009 & 2010 & 2011 & 2012 \\
\hline pt 1 & 3 & 2 & 1 & - & - & - & - & - & - & - & - & - \\
\hline pt 2 & - & 1 & 1 & - & 1 & 1 & - & 3 & - & 1 & - & 2 \\
\hline pt 3 & 2 & 3 & - & 2 & - & - & 1 & - & - & - & - & 1 \\
\hline
\end{tabular}

Source: http://ms.gov.pl/ (accessed on: 25.01.2015).

52 J. Piskorski, Przestępstwa..., op. cit., p. 264 oraz M. Szewczyk, Przestępstwa..., op. cit., pp. 1324-1325.

53 L. Tyszkiewicz, Przestępstwa..., op. cit., p. 1165.

54 Ibidem, p. 1165.

55 J. Piskorski, Przestępstwa..., op. cit., p. 265.

56 M. Budyn-Kulik, Komentarz..., op. cit., p. 582 and L. Tyszkiewicz, Przestępstwa..., op. cit., p. 1165. 
When analyzing the above data, it can be observed that the largest number of proceedings for an act provided for in Article 249 of the Penal Code was instituted in 2002 and 2006 (19 proceedings in each year); in these yearsthe municipal elections took place in our country. In 1999 no proceeding was initiated under the discussed provision.

When observing statistical data on the number of finally convicted adults under Article 249 of the Penal Code, one can observe minimal and occasionally occurring convictions for interference with the conduct of elections. It should be noted that convictions under pt 4 were not included, as there was no data in statistics available at the official website of the Ministry of Justice. It is noteworthy that the said provision was added to the Penal Code by the amendment of 23.01.2004.

\section{Infringement of the freedom to exercise electoral rights (Article $250 \mathrm{of}$ the Penal Code)}

Another prohibited act, provided for in Chapter XXXI, is voter intimidation (Article 250 of the Penal Code), thus the freedom of exercising the electoral rights. According to some authors, it is a common offence, so can be committed by every person, provided that it corresponds to the general characteristics of the object of legal and criminal liability ${ }^{57}$. It is sometimes argued that in the case of committing an offence abusing dependence, it will be an offence individual toward the $\operatorname{act}^{58}$.

The object of protection of provision of Article 250 of the Penal Code is unrestricted participation in elections and a referendum, free from influences ${ }^{59}$. Some provide safety, freedom, physical integrity of a person enjoying the right to vote as a side object of protection ${ }^{60}$.

A causative action here consists in influencing the way of voting of an individual, forcing him or her to vote or refraining from voting. Criminality of these behaviors depends on a mean used by a perpetrator, thus using the violence, the unlawful threat of violence or exploiting a situation of dependence will be a condition for criminality. Behaviors, where a perpetrator uses no aforementioned mean, are irrelevant from the point of view of regulation provided for in Article 250 of the Penal Code ${ }^{61}$.

57 Article 250. Anyone who, through the use of violence or the unlawful threat of violence, or by exploiting a situation of dependence, influences the vote of an eligible person, or forces such a person to vote, or not to vote is liable to imprisonment for between three months and five years.

58 L. Tyszkiewicz, Przestępstwa..., op. cit., p. 1166.

59 M. Budyn-Kulik, Komentarz..., op. cit., p. 582.

60 M. Szewczyk, Przestępstwa..., op. cit., p. 1327.

61 M.Jachimowicz, Przestępstwo naruszenia swobody głosowania (art. 250 k.k.), "Prokurator" 2009, No. 1, p. 92. 
Influencing the voting means shaping the content of the electoral act against the will of an eligible person, but in accordance with the will of a perpetrator, e.g. casting an invalid voice or casting a vote for a person, who is not actually supported. Forcing to vote covers not only casting a vote in the polling station. It will take place even when a voter casts an invalid vote, or in accordance with her or his will, or will take ballot papers out and hand them a perpetrator.

Putting pressure through the aforementioned means, so that a person willing to vote would not go to the polling station, but also physical stopping of such person, can be deemed as refraining from voting. Moreover, it covers all behaviors leading to the lack of possibility to cast a vote ${ }^{62}$.

The described act can be committed by both action and omission ${ }^{63}$. Some authors regard the given offence as a formal offence, others as a substantive offence. After an in-depth analysis, it seems justified to repeat the view saying that the act typified in Article 250 of the Penal Code is of consecutive character. Thus, influencing the way of voting of an eligible person, voting against her or his own will, or refraining from voting, will be the result of criminal behavior described in this provision ${ }^{64}$.

When the objective side is concerned, the discussed minor offence is of intentional character and can be committed only with the direct intent ${ }^{65}$.

The offence under Article 250 of the Penal Code is subject to a penalty of imprisonment from 3 months for up to 5 years.

Table 5. A number of proceedings instituted for an act under Article 250 of the Penal Code between 1999-2014

\begin{tabular}{|c|c|c|c|c|c|c|c|c|}
\hline \multirow{4}{*}{$\begin{array}{c}\text { Article } \\
250\end{array}$} & 1999 & 2000 & 2001 & 2002 & 2003 & 2004 & 2005 & 2006 \\
\cline { 2 - 10 } & 1 & 4 & 5 & 1 & 9 & 5 & 9 & 71 \\
\cline { 2 - 9 } & 2007 & 2008 & 2009 & 2010 & 2011 & 2012 & 2013 & 2014 \\
\cline { 2 - 9 } & 27 & 7 & 4 & 6 & 3 & 1 & 2 & 7 \\
\hline
\end{tabular}

Source: www.policja.pl (accessed on: 26.01.2015).

Table 6. Adults finally convicted under Article 250 of the Penal Code between 2001 and 2014

\begin{tabular}{|c|c|c|c|c|c|c|c|c|c|c|c|c|}
\hline \multirow{2}{*}{$\begin{array}{c}\text { Article } \\
250\end{array}$} & 2001 & 2002 & 2003 & 2004 & 2005 & 2006 & 2007 & 2008 & 2009 & 2010 & 2011 & 2012 \\
\cline { 2 - 11 } & - & - & - & - & 1 & - & - & - & - & - & 1 & 1 \\
\hline
\end{tabular}

Source: http://ms.gov.pl/ (accessed on: 26.01.2015).

62 L. Tyszkiewicz, Przestępstwa..., op. cit., p. 1165.

63 J. Piskorski, Przestępstwa..., op. cit., pp. 270-271.

64 Ibidem, p. 270-271.

65 M. Budyn-Kulik, Komentarz..., op. cit., p. 582. 
The largest number of proceedings instituted for an act under Article 250 of the Penal Code can be observed in 2006, in comparison to the remaining years; there were as many as 71 proceedings - in that year the municipal elections took place in Poland. The lowest number of initiated proceedings was in 1999, 2002, $2012-1$ each year (in 2002 also the municipal elections took place in our country).

When a number of convictions for the infringement of the freedom to exercise electoral rights is concerned, they took place only in: 2005, 2011 and 2012 - one each year.

\section{Electoral bribery (Article 250a of the Penal Code)}

Article $250 \mathrm{a}^{66}$ penalizes an offence of electoral bribery. In $\$ 1$ of this provision, the legislator criminalized electoral venality, whereas in $\$ 2$ electoral bribery. The first prohibited act is an individual offence, as it can be committed only by a person eligible to voting. The legislator does not indicates existence of particular features characterizing the object in the case of the second prohibited act, thus it is a common offence.

The subject of protection of Article 250a is an objective election honesty ${ }^{67}$, whereas the objectivity shall be construed as conducting the electoral act in accordance with believes of a voter ${ }^{68}$. The described provision, as R.A. Stefański notes, is to protect not only the correctness of elections, but also contribute to reduce the 'corruption foreground' 69 .

In the case of passive electoral bribery $(\$ 1)$, the causative action consists in accepting financial or personal benefit, or requesting such benefits for voting in a certain way. To the financial and personal benefit refers, in a very laconic way, Article $115 \S 4$ of the Penal Code ${ }^{70}$. It is worth recalling theses formulated on the basis of this regulation.

66 Article 250a. $\$ 1$ : Anyone who, being entitled to vote, accepts financial or personal benefit or requests such benefits for voting in a certain way is liable to imprisonment from three months to five years. $\$ 2$. Anyone who provides financial or personal benefit to a person entitled to vote in order to persuade him or her to vote in a certain way, or for voting in a certain way, is liable to the same penalty. $₫ 3$. In the case of lesser significance, the offender of the act specified in $\$ \$ 1$ or 2 is subject to a fine, restriction of liberty or imprisonment for up to two years. $\$ 4$. If the offender of the act specified in $\S 1$ or $\$ 3$ in conjunction with $\$ 1$ notified the relevant prosecution body of the fact and circumstances of the offence before this authority learned about them, the court will apply an extraordinary mitigation of punishment, and may even waive inflicting a penalty.

67 M. Szewczyk, Przestępstwa..., op. cit., p. 1331.

68 R. A. Stefański, Przestępstwo korupcji wyborczej (art. 250a), "Prokuratura i Prawo" 2004, No. 4, p. 70.

69 Ibidem, p. 70.

70 Article $115 \$ 4$. Materia or personal benefit is a benefit for the person hero himself, or a third party. 
The financial benefit is simply increasing of assets or decreasing liabilities; it includes inter alia money, securities, property rights and items of material value ${ }^{71}$. Also a loan bearing no interest or bearing grossly understated interest, can be regarded as the financial benefit ${ }^{72}$. The term 'personal benefit' shall be construed as meeting other than material needs, or such needs, in which prevailing importance is attributed to intangible benefit. A. Marek names as examples of the personal benefit inter alia: promotion, awarding the medal, and even providing gratuitous sexual services $^{73}$. Granting a leave or reducing duties might also be a personal benefit ${ }^{74}$. It is worth mentioning that casting an invalid vote falls within the scope of the term of voting in a certainway ${ }^{75}$. The prohibited act provided for in $\$ 1$ is of a formal character and may be committed by both action and omission.

The essence of an active electoral bribery $(\$ 2)$ is providing the above mentionedbenefit to a person entitled to vote in order to persuade her or him to vote in a certain way or for voting in a certain way. The fact whether the offered benefit has been accepted or not is irrelevant from the point of view of this offence ${ }^{76}$. It is a formal offence, of the action ${ }^{77}$.

It is worth to signalize in this place that our legislator omitted penalization of acceptance and giving promise of the benefit. This move should be deemed as intentional, as giving promises by candidates to voters, often not kept, is inseparably connected with the conduct of the election campaign ${ }^{78}$. There emerged the postulate ${ }^{79}$ in the literature to penalize these behaviors, however it was refused.

The subject side of the offence provided for in $\$ 1$ consists in intentionality in the form of the direct directional intent ${ }^{80}$, what results from the wording and drafting of this provision.

Minor offences provided for in $\$ 1$ and 2 of Article 250a are subject to a penalty of imprisonment from 3 months for up to 5 years.

It is worth to draw attention to the wording of $\$ 3$ of this provision, providing for mitigated punishment due to the case of lesser significance. The Supreme Court in a judgment of 9 October 1996 stated that 'when considering whether there is a case of lesser significance in the given instance, subjective-objective features of the act

71 A. Marek, Kodeks..., op. cit., p. 312.

72 M. Szewczyk, Przestępstwa..., op. cit., p. 1333.

73 A. Marek, Kodeks..., op. cit., p. 312.

74 M. Szewczyk, Przestępstwa..., op. cit., p. 1334.

75 R.A. Stefański, Przestępstwo..., op. cit., p. 71.

76 Ibidem, p. 75.

77 M. Budyn-Kulik, Komentarz..., op. cit., p. 583.

78 R. A. Stefański, Przestępstwo..., op. cit., p. 76.

79 J. Skorupka, Podstawy karania korupcji w kodeksie karnym de lege lata i delege ferenda (wybrane zagadnienia), "Państwo i Prawo" 2003, No 12, p. 78 et seq.

80 M. Budyn-Kulik, Komentarz..., op. cit., p. 583. 
Offences Against Elections and Referenda - Selected Legal, Criminal...

shall be taken into consideration, emphasizing these elements, which are specific for the given type of offences. For the case of lesser significance is the privileged form of the act having feature of an offence of a basic type, characterized by majority of mitigating subjective-objective elements ${ }^{81}$. The act provided for in $₫ 3$ is subject to a fine, limitation of liberty or imprisonment for up to 2 years.

In $\$ 4$ the legislator regulated institution of active repentance; taking advantage of it causes obligatory mitigation of punishment. The court may also waive inflicting a penalty. It should be emphasized that only a perpetrator of an offence provided for in $₫ 1$ (passive electoral bribery) and a perpetrator, whose behavior constitutes the case of lesser significance are entitled to take advantage of the benefit of the active repentance.

Table 7. A number of proceedings initated for an act under Article 250a of the Penal Code between 1999 and 2014

\begin{tabular}{|c|c|c|c|c|c|c|c|c|c|c|c|c||}
\hline \multirow{2}{*}{$\begin{array}{c}\text { Article } \\
250 a\end{array}$} & 2003 & 2004 & 2005 & 2006 & 2007 & 2008 & 2009 & 2010 & 2011 & 2012 & 2013 & 2014 \\
\cline { 2 - 25 } & 4 & 4 & 7 & 62 & 20 & 4 & 2 & 57 & 34 & 9 & 5 & 62 \\
\hline
\end{tabular}

Source: www.policja.pl (accessed on: 26.01.2015).

Table 8. Adults finally convicted under Article 250a of the Penal Code between 2001 and 2012

\begin{tabular}{|l|c|c|c|c|c|c|c|c|c|c|c|c||}
\hline $\begin{array}{l}\text { Article } \\
250 a\end{array}$ & 2001 & 2002 & 2003 & 2004 & 2005 & 2006 & 2007 & 2008 & 2009 & 2010 & 2011 & 2012 \\
\hline$\S 1$ & - & - & - & - & - & - & - & 5 & 5 & 1 & 47 & 13 \\
\hline$\S 2$ & - & - & - & - & - & - & - & 12 & 9 & 1 & 15 & 7 \\
\hline$\S 3$ & - & - & - & - & - & - & - & - & 3 & 7 & 3 & 11 \\
\hline $\begin{array}{l}\S 3 \text { in } \\
\text { conjunction } \\
\text { with §1 }\end{array}$ & - & - & - & - & - & - & - & 3 & - & - & 10 & 1 \\
\hline $\begin{array}{l}\S 3 \text { in } \\
\text { conjunction } \\
\text { with §2 }\end{array}$ & - & - & - & - & - & - & - & 1 & - & - & 4 & 1 \\
\hline
\end{tabular}

Source: http://ms.gov.pl/ (accessed on: 26.01.2015).

When analyzing the above statistical data, it should be kept in mind that the provision of Article 250a of the Penal Code entered into force on 1 July $2003^{82}$. The

81 R.A. Stefański, Przestępstwo..., op. cit., p. 78.

82 Wyrok Sądu Najwyższego z dnia 9 października 1996 r., V KKN 79/96 [Judgement of the Supreme Court of 9 October 1996, V KKN 79/96], "Orzecznictwo Izby Karnej i Wojskowej Sądu Najwyższego" 1997, N.o 3-4, item 27. 
largest number of initiated proceedings on electoral corruption can be observed in 2006 and 2014, when 62 proceedings were initiated in each year. Whereas, only 2 proceedings were initiated in 2009.

The first finally binding judgments for an act under Article 250a of the Penal Code were given in 2008. The largest number of final convictions for both electoral corruption and electoral bribery, took place in 2001 (47 for an act under $\$ 1,15$ for an act under $\$ 2$ ). In the same year, 14 persons were convicted for the case of lesser significance.

\section{Breaching the secrecy of voting (Article 251 of the Penal Code)}

The last prohibited act provided for in Chapter XXXI of the Penal Code is breaching the secrecy of voting. The offence under Article 251 of the Penal Code ${ }^{83}$ is a common offence, thus can be committed by every person, corresponding to the general characteristics of the object of legal and criminal liability.

The object of protection of the said provision is, guaranteed in Article 96 section 2, Article 97 section 2, Article 127 section 1 and Article 169 section 2 of the Constitution of the Republic of Poland ${ }^{84}$, the rule of the secrecy of voting.

The said prohibited act is of a substantive character, whereas acquiring knowledge of another person's way of voting, against the wish of that person, is a result of a criminal behavior. It can be committed by both action and omission ${ }^{85}$. Acquiring knowledge on another person's way of voting, against the wish of that person, constitutes the essence of causative action.

The activity feature 'acquiring knowledge on the way of voting' means 'taking any action leading to acquiring knowledge on the way of voting, e.g. peeping at a person casting a vote, identifying an anonymous ballot paper ${ }^{86}$. Consent of a person casting a vote lead to exclusion of criminality of the act ${ }^{87}$.

This offence may be committed with intentional guilt. There is a dispute in the literature on intent. Some authors claim that the said act can be committed only with

83 Ustawa z dnia 13 czerwca 2003 r. - o zmianie ustawy Kodeks karny oraz niektórych innych ustaw (Dz.U. z 2003 r. Nr 111, poz.1061) [Journal of Laws of 2003 No. 111 item 1061]. Article 251. Anyone who, in violation of the rules on the secrecy of voting, acquires knowledge of another person's way of voting, against the wish of the voter, is liable to a fine, the restriction of liberty or imprisonment for up to two years.

84 Konstytucja Rzeczypospolitej Polskiej z dnia 2 kwietnia 1997 r. (Dz.U. z 1997 r. Nr 78, poz. 483 z późn.zm.) [Journal of Laws of 1997 No. 78 item 483 as amended].

85 M. Budyn-Kulik, Komentarz..., op. cit., p. 584.

86 M. Szewczyk, Przestępstwa..., op. cit., p. 1137.

87 L. Tyszkiewicz, Przestępstwa..., op. cit., p. 1167. 
Offences Against Elections and Referenda - Selected Legal, Criminal...

direct intent ${ }^{88}$, whereas remaining ones provide for occurrence of both forms of intent ${ }^{89}$.

The offence of breaching the secrecy of voting is subject to a fine, the restriction of liberty or imprisonment for up to 2 years.

Table 9. A number of proceedings instututed for an act under Article 251 of the Penal Code between 1999 and 2014

\begin{tabular}{||c|c|c|c|c|c|c|c|c|}
\hline \multirow{4}{*}{$\begin{array}{c}\text { Article } \\
251\end{array}$} & 1999 & 2000 & 2001 & 2002 & 2003 & 2004 & 2005 & 2006 \\
\cline { 2 - 9 } & - & 4 & - & - & 1 & 3 & 3 & 5 \\
\cline { 2 - 9 } & 2007 & 2008 & 2009 & 2010 & 2011 & 2012 & 2013 & 2014 \\
\cline { 2 - 9 } & 5 & 1 & 1 & 1 & 3 & - & 1 & 1 \\
\hline
\end{tabular}

Source: www.policja.pl (accessed on: 26.01.2015).

It is clear from data included in the table that proceedings for an offence under Article 251 of the Penal Code were institutedincidentally.

Table 10. Adults finally convicted under Article 251 of the Penal Code between 2001 and 2012

\begin{tabular}{|c|c|c|c|c|c|c|c|c|c|c|c|c|}
\hline \multirow{2}{*}{$\begin{array}{c}\text { Article } \\
251\end{array}$} & 2001 & 2002 & 2003 & 2004 & 2005 & 2006 & 2007 & 2008 & 2009 & 2010 & 2011 & 2012 \\
\cline { 2 - 13 } & - & - & - & 1 & - & 1 & - & - & - & - & - & - \\
\hline
\end{tabular}

Source: http://ms.gov.pl/ (accessed on: 26.01.2015).

When proceedings instituted for an act under Article 251 of the Penal Code are concerned, the largest number was observed in 2006 and 2007. In 1999, 2000, 2002 and 2012 no proceeding for an act under the said provision was instituted.

In 2001 and 2012, the provision of Article 251 of the Penal Code constituted a basis for issuing the final judgment only twice, it took place in 2004 and 2006.

\section{Summary}

The size of crime against elections and referenda can be discussed after a scrupulous analysis of the police and court statistics. The particular significance is assigned to the second one, as it is the most credible information on the scale of crime in Poland. It is explained by the fact that it presents a number of adults convicted with valid and finally binding judgment.

89 M.Budyn-Kulik, Komentarz..., op. cit., p. 584 oraz M. Szewczyk, Przestępstwa..., op. cit., p. 1138. 
Summarizing statistical data concerning offences against elections and referenda (Articles 248-251 of the Penal Code) one can observe that they do not constitute a serious threat, in terms of quantity. Unfortunately, data for 2013 and 2014 have not been yet included in the above court statistics.

It results from the police statistics that proceedings for acts provided for in the Chapter XXXI of the Penal Code are initiated very rarely. Whereas observing data of the Ministry of Justice it can be immediately noted that finally binding convictions for acts under the Chapter XXXI take place episodically.

In both statistics it is difficult to observe any regularities, only obvious dependences between a number of instituted proceedings and years in which elections took place, are noticeable. After analyzing statistical data and correlating them with a number of persons convicted in general in particular years, it can be definitely noted that a threat of offences against the elections and referenda is indeed marginal. It cannot be ignored however, due to repeatedly emphasized importance of the proper use of institutions of direct and indirect democracy for the functioning of the state and society. This phenomenon should be steadily examined and regularities related to committing prohibited acts against elections and referenda verified.

\section{BIBIOGRAPHY}

Budyn-Kulik M., Komentarz do rozdziału XXXI k.k., (in:) M. Mozgawa (ed.), M. Budyn-Kulik, P. Kozłowska-Kalisz, M. Kulik, Kodeks Karny. Komentarz, Warszawa 2012

Hołyst B., Kryminologia, Warszawa 1994

Jachimowicz M., Przestępstwo naruszenia swobody głosowania (art. 250 k.k.), Prokurator 2009, Nr 1 Kowalski S., Karnoprawna ochrona wykazu podpisów wyborców w wyborach samorządowych, Prok. i Pr. 2014, Nr 9

Kozielewicz W., Rozdział IX. Przestępstwa przeciwko wyborom i referendum (in:) L. Gardocki (ed.), System Prawa Karnego. Przestępstwa przeciwko państwu i dobrom zbiorowym, t.8, Warszawa 2012

Łabuda G., Komentarz do art. 248 k.k., (in:) J. Giezek (ed.), Kodeks karny. Część szczególna. Komentarz, Warszawa 2014

Marek A., Kodeks Karny. Komentarz, Warszawa 2010

Piskorski J., Przestępstwa przeciwko wyborom i referendum, (in:) M. Królikowski, R. Zawłocki (ed.), Kodeks Karny. Część Szczególna. Komentarz do art. 222-316, Warszawa 2013

Skorupka J., Podstawy karania korupcji w kodeksie karnym de lege lata i de lege ferenda (wybrane zagadnienia), PiP 2003, nr 12

Szewczyk M., Przestępstwa przeciwko wyborom i referendum, (in:) A. Zoll (ed.), Kodeks Karny. Komentarz do art. 117-277 k.k., Warszawa 2013

Tyszkiewicz L., Przestępstwa przeciwko wyborom i referendum, (in:) M. Filar (ed.), Kodeks Karny. Komentarz, Warszawa 2012 